\begin{tabular}{|c|c|c|}
\hline $\begin{array}{l}\text { An International Biannual Open Access } \\
\text { Peer-Reviewed/Refereed Journal } \\
\text { JOURNAL OF GLOBAL RESOURCES } \\
\text { Published by: ISDESR, Jaipur, India }\end{array}$ & 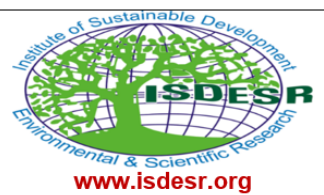 & $\begin{array}{r}\text { ISSN: } 2395-3160 \text { (Print) } \\
\text { ISSN: } 2455-2445 \text { (Online) } \\
\text { January 2022, Volume 08 (01) } \\
\text { DOI Prefix: } 10.46587 / J G R\end{array}$ \\
\hline
\end{tabular}

07

\title{
SERVICE CENTRES IN RURAL DEVELOPMENT : A CASE STUDY OF JAUNPUR DISTRICT, UTTAR PRADESH
}

\author{
Dinesh Kumar \\ Assistant Professor Govt. M. G. M. Postgraduate College, Itarsi, (M.P.) India \\ Email: kumardinesh.bhu2014@gmail.com
}

How to cite this paper:

Kumar, Dinesh (2022) Service centres in rural development : A case study of Jaunpur district, Uttar Pradesh, Journal of Global Resources, Vol. 08 (01)

DOI:

10.46587/JGR.2022.v08i01.007

Received: 12 Sep. 2021

Reviewed: 21 Oct. 2021

Revised: 01 Nov. 2021

Final Accepted: 14 Nov. 2021

OPEN 0 A C C ESS

Freely available Online

www.isdesr.org

\begin{abstract}
This paper attempts to deal with the identifying the service centers and calculation of the spatial arrangement with complementary area of service centres in Jaunpur district Jaunpur district of Uttar Pradesh. The study area is situated in Eastern Uttar Pradesh of the Middle Ganga Plain. The study is exclusively based on secondary data collected at block level from different offices. The centrality score has been calculated on the basis of three type of indices like functional centrality index, working population index and tertiary population index. There are 31 function or services selected judicially from five sectors (administrative, agricultural and financial, educational, health and transport and communication) to measure the centrality of service centre. The thissen polygon and berry breaking point method has been used for measure the complementary area. Total 88 service centres have been identified as first, second, third, fourth and fifth order service centre. The number of I, II, III, IV, and V order centres accounts for $43,24,16,4$, and 1 respectively.
\end{abstract}

Key words: Service Centre, Function Centrality Index, Complimentary Area. 


\section{Introduction}

In any region, the developmental growth does not start everywhere and all alone, it starts in the form of points or development poles, with various intensities then it extends along different channels with varying terminal effects to the whole of economy (Perroux, 1955). Any permanent settlements who's having some functions for fulfill the socio and economic demands of nearby areas may be known as a Service Centre. The population, existing infrastructure facilities, distance and movement of the people have been used to identify the service center and complementary area. The studies regarding service centre were done by many scholars like Hagerstrand (1952), Berry (1967) and Sen et al. (1971). Some scholars have also attempted empirical studies to test theories of Christaller (1933) and Losch (1954) in different region. The important among them are Smailes (1944), Perroux (1950), Brush (1953), Bracey (1953), Misra and Shivalingaih (1970), Misra (1972, 1974), Roy and Patil (1977) etc. Misra, R.P (1974) propounded the concept of 'Growth Foci' by integrating the basic elements of central place theory, Growth Pole theory and spatial diffusion of innovation theory and proposed five- tier hierarchy from top to bottom as Growth Pole (national level), Growth Centre (regional level), Growth Point (sub-regional level), Service Centre (micro regional level), Growth Foci as central village (local level). Further, some of notable scholars who had applied geospatial tools and techniques for regional planning were Mishra (1985), R.K. Mallick (1998), L.R. Yadav and R.S. Singh (2009), Sarkar (2018), Khan and Ahamad (2013), Chaturvedi (2013), etc.

\section{Objectives}

The study has attempted:

(i) To identify the service centers

(ii) To observe the spatial arrangement of service centres and

(iii) To study the complementary area and spatial-functional gaps of service centre in the area.

\section{Study Area}

Jaunpur district $\left(25^{\circ} 26^{\prime} \mathrm{N}\right.$ to $26^{\circ} 11^{\prime} \mathrm{N}$ and $82^{\circ} 8^{\prime} \mathrm{E}$ to $\left.83^{\circ} 5^{\prime} \mathrm{E}\right)$ is situated in Eastern Uttar Pradesh of the Middle Ganga Plain. The study area has cover $4035 \mathrm{~km}^{2}$ with having population of 44,94,204 persons (Census 2011). There are ten rivers which flow in the district namely Gomati, Sai, Varuna, Basuhi, Pili, Tambura, Mongar, Gangi, Besu and Nand river. The Gomati and Sai Rivers flow in middle part of the district (Fig. 1). The surface of district is about flat while some undulation is seen in the part of riverine areas.

\section{Data Base and Methodology}

The present study is based on secondary data collected from the different government offices like Primary Census Abstract of Uttar Pradesh (2011), District Census Handbook, Agriculture Report from Krishi Bhavan, Zila Sankhikiya Patrika from Vikas Bhavan and different websites. The data were tabulated and analyzed for composite function index by using centrality function index (CFI), working population index $(\mathrm{WI})$ and tertiary population index $(\mathrm{TI})$. Centrality index calculated with the help of weighting technique. Here also used the berry "Breaking Point Equation" and Thiessen polygon methods for marking the service area of service centre. Micro Soft excel and Arc GIS 10.2 software have been used for computation and cartographic presentation in regional variation of development.

\section{Identification of Service Centre}

In present study to pointing all the 3287 villages of the district for identifying the order of service centres; hence sampling techniques have been used to select the potential service centres. In such a way, as much as 88 potential villages (centres) are selected to measure the hierarchy levels of centres by considering the criteria given below: 
(i) A stable settlement which has minimum 2000 population;

(ii) It must have at least five basic functions from all functional groups, like education, health, and transport, etc.;

(iii) The service centre should be connected by rail or road transport ;

(iv) It must constitute at least 0.10 percent share of the total population; and

(v) It must account at least 0.13 values as functional centrality index.

In some cases, the first criteria related to the required number of populations is ignored where there is high functional availability due to some socio, economic and political reasons (Table 1).

Figure 01: Study Area

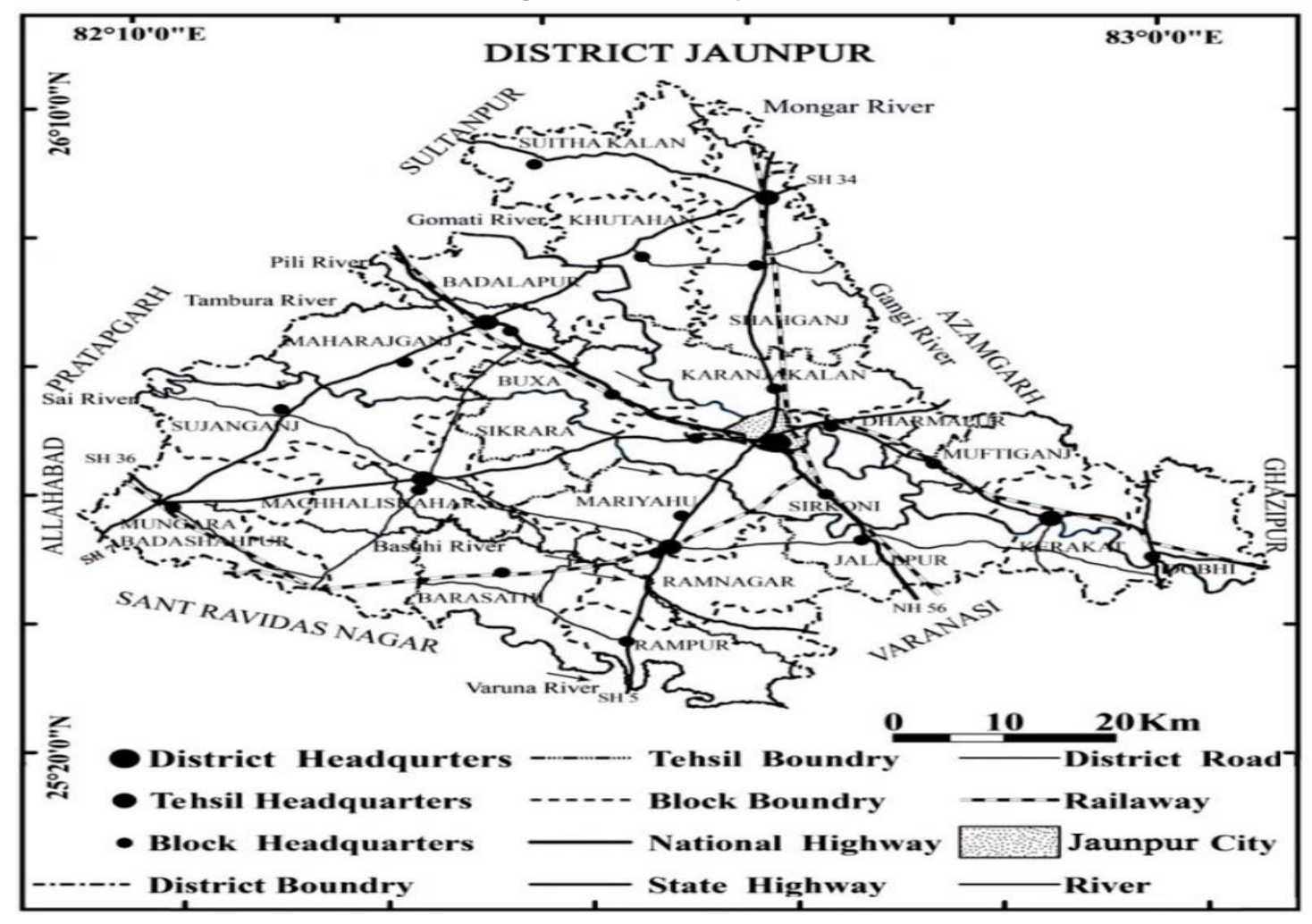

\section{Result and Discussion \\ Measurement of Centrality}

Several Indian scholars have also computed the centrality of a service center on the basis of population engaged in retail sectors or commercial activities or tertiary services (Singh, 1966; Singh 1971; Singh, 1977). Bhatt (1976) had used a weighting technique to compute the centrality of service centers. Some scholars have measured the functional hierarchy of settlements based on people's choice of centers to fulfill their needs (Sen et al., 1971; Kayastha and Mishra, 1981; Mishra, 1985). In this study, the hierarchy of service centres has been derived by using Composite Functionality Index (CFI) based on three indices (i) Functional Centrality Index, (ii) Working Population Index, and (iii) Tertiary Population Index.

\section{Functional Centrality Index Value (FCl)}

$\mathrm{FCl}$ is the measurement of functional availability of any centre. It has been computed by adding the all-available functions weightage of any centre and then it is divided by the combined weightage of all selected centres. In this study agricultural and finance (Fig. 2 A), educational (Fig. 2 B), health (Fig. $2 \mathrm{C}$ ), transport and communication (Fig. 2 D) and transport type 31 functions or services have been taken for the computation of $\mathrm{FCl}$. 
This may be calculated as:

Where, $\mathrm{FCl}=$ Functional centrality index

$$
\mathrm{FCI}=\sum_{i}^{n} \frac{W i d}{w} \times 100
$$

Wid $=$ Weightage for $\mathrm{d}^{\text {th }}$ centre

$\mathrm{W}=$ Total Weightage of all the centres.

\section{Working Population Index (WI)}

WI has been calculated after using the following formula:

Where WId $=$ Worker index of $d^{\text {th }}$ centre

$$
\mathrm{WId}=\frac{\mathrm{Wd}}{\mathrm{Wt}} \times 100
$$

Wd $=$ Working population of $d^{\text {th }}$ centres

$\mathrm{Wt}=$ Total working population in the district

The Tertiary Population Index (TI)

$\mathrm{TI}$ is computed using the following formula:

$$
\text { TId }=\frac{\mathrm{Td}}{\mathrm{Tt}} \times 100
$$

Where Tld $=$ Tertiary population index of $d^{\text {th }}$ centre

$\mathrm{Td}=$ Tertiary population of $\mathrm{d}^{\text {th }}$ centre

$\mathrm{Tt}=$ Total Tertiary population in the district

Finally, after taking the average values of these three indices, the Composite Functional Index (CFI) for a particular service centre has been computed. This can be expressed as:

$$
\mathrm{CFI}=\frac{\mathrm{FCI}+\mathrm{WId}+\mathrm{TId}}{3}
$$

Similarly, the CFI of all service centres has been calculated. High CFI show the high centrality index mean more functional availability and vice versa.

\section{Hierarchy of Service Centre}

There are 88 rural settlements have been identified as service centres in the district with term and conditions. On the basis of the centrality score, the service centres have been classified into five hierarchic orders, using the value of mean and standard deviation. Those centres get the low score treated as the first-order service centre and highest scorer centre treated as the fifth-order centre.

\section{First Order Service Centre}

There are forty-three centres marked as first service centre with the centrality score of 0.1 to 0.25 . These centres fulfill local people's need with limited choices and relatively lower order of functions. Most of them are equipped with a basic level of services like sub-post office, primary co-operative societies, family planning centres, and sub-centers, sub-primary health centre, seed and fertilizer depot, etc.

\section{Second-Order Service Centre}

There are twenty-four centres counted in second-order which are Barsathi, Sujanganj, Meerganj, Paharpur, Singaramau, Thana Gaddi, Suetha Kalan, Trilochan Mahadev, Dharmapur, Sirkoni, Karanja Kalan, Karchhuli, Deokali, Dhaniya Mau, Kachgaon, Newariha, Jamunipur, Samodhpur, Surapur, Mani Kalan, Habibpur, Fatehganj, Sarai Deeh, Kunwarpur which is the major market in the district. These centrality score of these centres are $0.25-0.5$. It has been sub PHC, senior secondary school, agriculture services, co-operative bank, agricultural credit society, branch office, roadways bus stop etc. for the influence area. 


\section{Third Order Service Centre}

Sixteen centres at block level and tahsil namely Mongra Badshahpur, Khetasarai, Khuthan, Badlapur, Jalalpur, Rampur, Naupedwa, Muftiganj, Chandwak, Gaura Badashahpur, Baksha, Jafarabad, Pali, Mahrajganj, Sikrara, Jamalapur have been identified as third order service centres. In this order centres are mostly big markets and block headquarters with composite centrality index value range from 0.5 to 10 . Transport facilities, along with the spatial location of such centres have made a distinction from the lower order centres. It also has some administrative services like Police station, Post office, telephone exchange, electricity office etc.

Table 01: Weighted Score for the Selected Functions in Jaunpur District

\begin{tabular}{|c|c|c|c|c|}
\hline $\begin{array}{l}\text { Functional } \\
\text { Group }\end{array}$ & $\#$ & Selected Services & $\begin{array}{c}\text { Number of } \\
\text { Services }\end{array}$ & $\begin{array}{c}\text { Weighted } \\
\text { Score }\end{array}$ \\
\hline \multirow[t]{7}{*}{ Health } & 1 & Hospital Allopathic & 58 & 56.67 \\
\hline & 2 & Family Welfare Centre & 46 & 71.45 \\
\hline & 3 & Maternity And Child Welfare Centre & 82 & 40.08 \\
\hline & 4 & Veterinary Hospital & 46 & 71.45 \\
\hline & 5 & Community Health Centre & 22 & 149.40 \\
\hline & 6 & Primary Health Centre & 29 & 113.34 \\
\hline & 7 & Primary Health Sub Centre & 72 & 44.41 \\
\hline \multirow[t]{4}{*}{ Education } & 8 & Govt. Secondary School & 566 & 5.80 \\
\hline & 9 & Govt. Senior Secondary School & 151 & 21.76 \\
\hline & 10 & Govt. Degree College & 37 & 88.83 \\
\hline & 11 & Govt.-Polytechnic & 4 & 88.83 \\
\hline \multirow{5}{*}{$\begin{array}{l}\text { Agricultural and } \\
\text { Finance }\end{array}$} & 12 & Nationalized Bank & 145 & 22.66 \\
\hline & 13 & Co-Operative Bank & 52 & 63.21 \\
\hline & 14 & Agricultural Credit Society & 224 & 14.67 \\
\hline & 15 & Mandis & 4 & 1095.66 \\
\hline & 17 & Cold Storage & 22 & 149.40 \\
\hline \multirow{9}{*}{$\begin{array}{l}\text { Transport and } \\
\text { Communication }\end{array}$} & 18 & Branch Office & 26 & 126.42 \\
\hline & 19 & Post Office & 391 & 8.40 \\
\hline & 21 & BSNL Exchange & 69 & 47.63 \\
\hline & 22 & Public Bus Service & 188 & 17.48 \\
\hline & 23 & Roadways Bus Stop & 33 & 99.60 \\
\hline & 24 & Railway Station & 32 & 102.71 \\
\hline & 25 & National Highway & $66.49 \mathrm{~km}$ & 49.43 \\
\hline & 26 & State Highway & $332.23 \mathrm{~km}$ & 9.89 \\
\hline & 27 & Major District Road & $219.00 \mathrm{~km}$ & 7.50 \\
\hline \multirow[t]{4}{*}{ Administrative } & 28 & Police Station & 27 & 121.74 \\
\hline & 29 & Block Headquarters & 22 & 156.52 \\
\hline & 30 & Tahsil Headquarters & 6 & 547.83 \\
\hline & 31 & District Headquarters & 1 & 3287.00 \\
\hline
\end{tabular}

Source: Calculated by the author on basis of Census 2011

\section{Fourth Order Service Centre}

There are four centres at Tahsil level namely Mariyahu, Shahganj, Machhalishahar, and Kerakat are occupy the fourth order in the hierarchy with the composite centrality index value range from 10 to 20. These four centres are Tahsils headquarters which CFI values are more than ten like 12.99 (Mariyahu), 12.25 (Shahganj), 12.14 (Machhalishahar), and 11.5 (Kerakat). Relatively high FCI with high Weighted Index and Tertiary Index values are responsible for their current position as a fourth-order centres. Here the administrative institutions, as well as infrastructural advantages, play a significant role behind its relative functional effect compare to other lowerorder centres.

\section{Fifth Order Service Centre}

The Jaunpur with CFI value 24.10 is only one fifth-order service centre. It is the district headquarters and situated in central location. Jaunpur city has huge population base (180362 
persons) of the district. At this service centre the majority of the functional services are available in huge quantity and best quality. This centre has been well connected through National highway (NH-31), two big railway station (Jaunpur junction and Jaunpur city) both of at the main route of Lucknow, Kanpur, and Delhi via Faizabad and Sultanpur. It has district headquarters and many other services. Because of these facts, it works as the heart for the whole artery of the district, pumping the goods and services to vast hinterlands.

Figure 02: Functional Centrality Index Value (FCl)

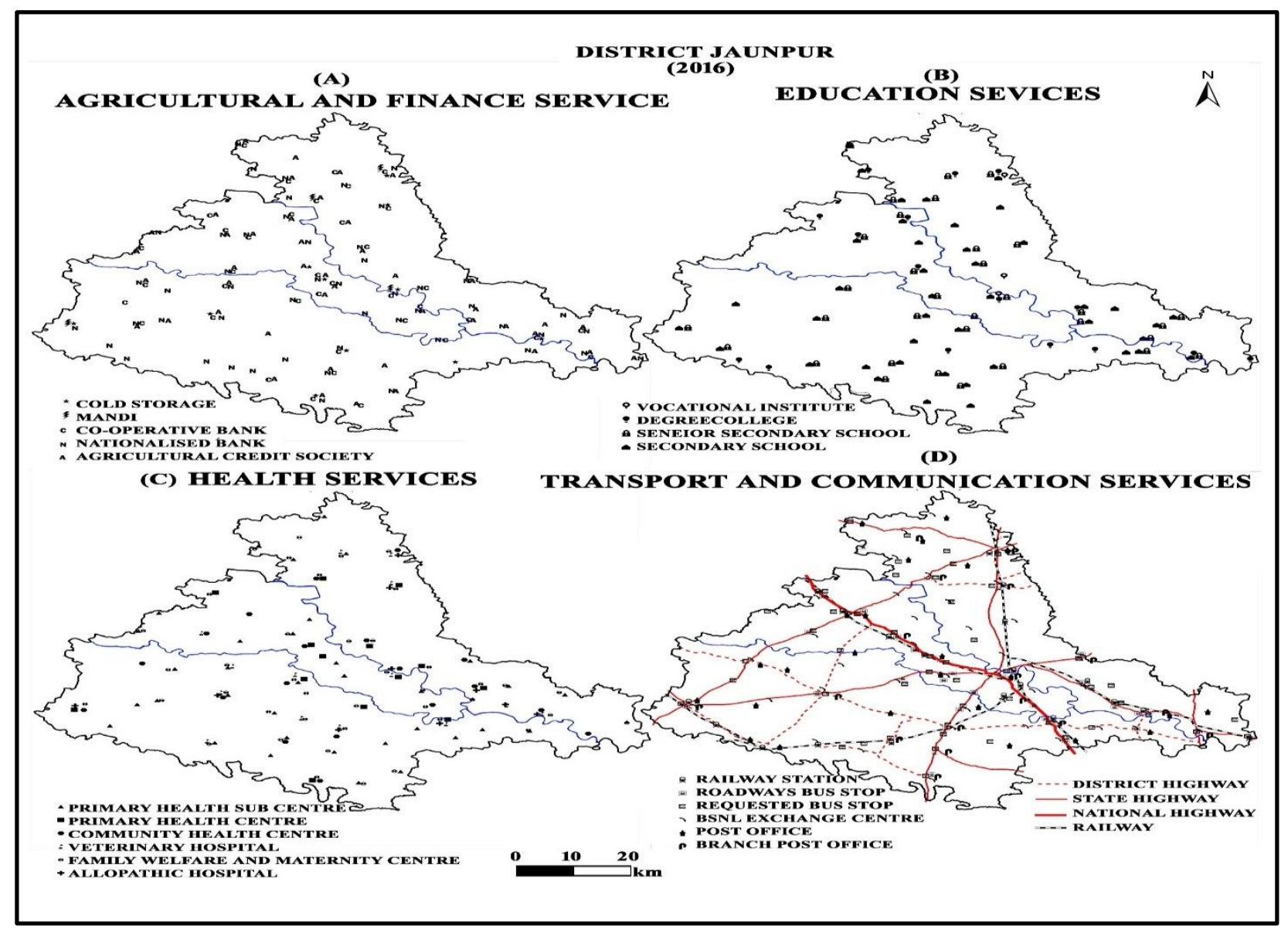

\section{Complementary Area of Service Centre}

Estimation of complementary area of Service Centres After identification of service centres, the estimation of zone of influence at each level in the functional hierarchy is a very challenging task of service centre study. The area which is served by a particular centre is known as its complementary region or zone of influence or hinterland. In present study, delamination of the complementary area has done by following methods:

\section{A statistical or theoretical method}

2. Qualitative or empirical methods

Then by the Berry method of 'Breaking Point Equation' to derive the hinterlands of market centres for retail distribution with Thiessen Polygons Method (1911). This method has been used in the present investigation to demarcate the boundary of the service area between two centres. This method can be expressed as:

Where,

$$
\mathrm{P}=\frac{\mathrm{d}^{2}}{1+\sqrt{\frac{C 1}{C 2}}}
$$

$\mathrm{P}=$ Common point where two hinterlands meet measured from the later centre 
C1 = Composite Functional Index of centre ' 1 '

$\mathrm{C} 2$ = Composite Functional Index of centre '2'

$\mathrm{d}=$ Distance between the two centres.

Figure 03: Hierarchy of Service Centre

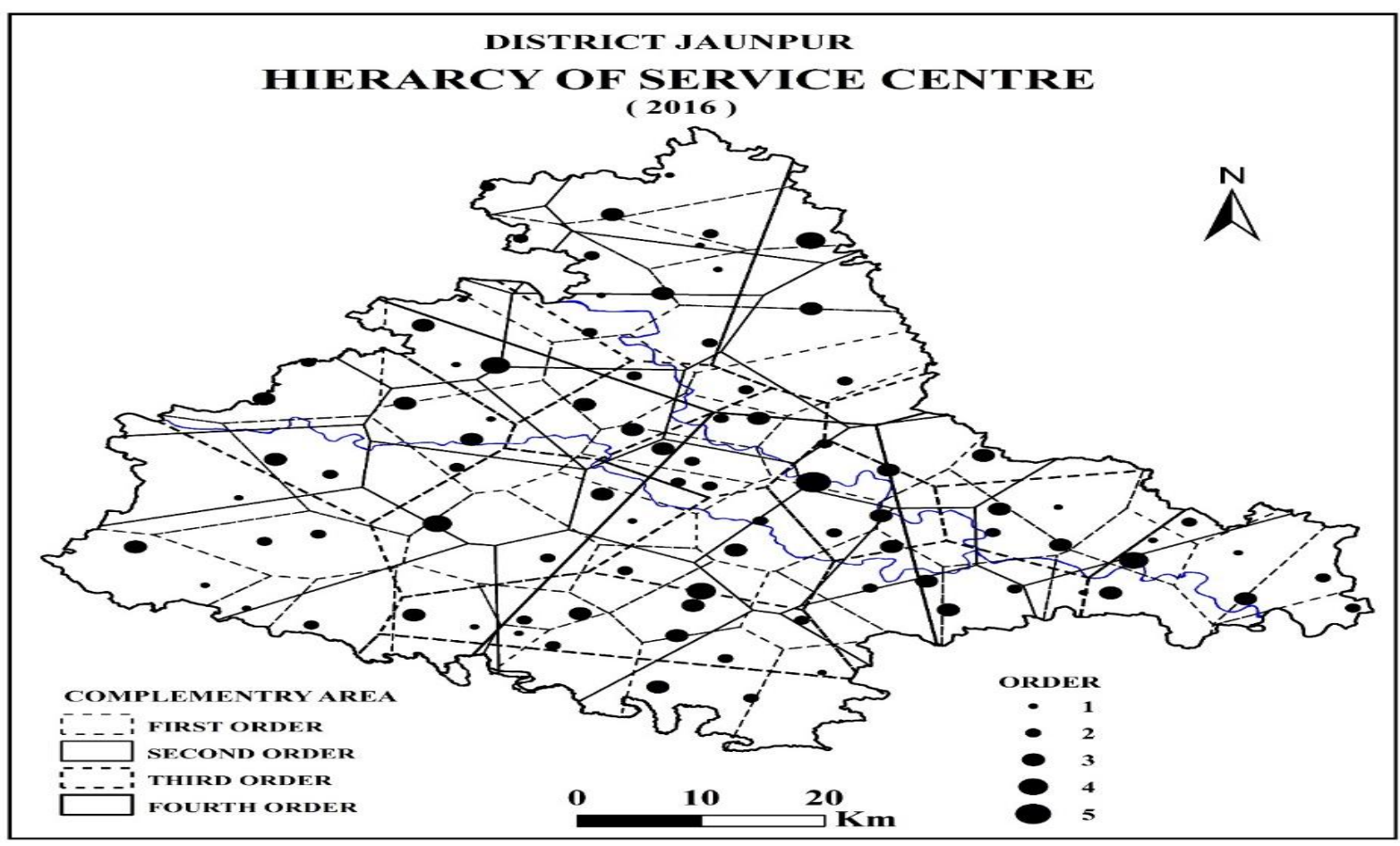

There are 43 first order service centres provide small scale services to the surrounding villages. The hinterlands of these order are about to $45 \mathrm{sq}$. $\mathrm{km}$. The distance between two centre is about 5 to $7 \mathrm{~km}$. However, some spatial gaps pertaining to first order centres were marked during analysis which needs due consideration for the proper supply of goods and services at grass -root level. The 25 centres of second order mainly located between third order service centre and serve the settlement which situated about $10 \mathrm{~km}$. The hinterlands of these order are about to $90 \mathrm{sq}$. km. Sixteen third order centres mostly of block headquarters and market centres. The average distance between these centres about $15 \mathrm{~km}$ and the complementary area of these order is about to $190 \mathrm{~km}^{2}$. Four order centres are well connected with metalled road. These are mostly situated in surrounding the district headquarters at the distance of about 25 to $30 \mathrm{~km}$ and the complementary area of these order is about to $800 \mathrm{sq}$. km. The whole area of study is the complementary area of fifth order of service centre. The people of the study area are totally dependent for the administrative work in these centres. (Fig.3).

\section{Conclusion}

The concluding points are that any permanent settlements who's having some functions for fulfill the socio and economic needs of surrounding areas may be known as a Service Centre. The study area is situated in Eastern Uttar Pradesh of the Middle Ganga Plain and cover 4035 sq. $\mathrm{km}$. with having population of $44,94,204$ persons. In this study total 88 potential villages (centres) have been selected to measure the hierarchy levels of centres by considering the criteria of centrality function index (CFI), working population index (WI) and tertiary population index (TI). There are forty-three centres marked as first service centre which score the centrality value of 0.1 to 0.25 . these centres have provided the primary services like sub-post office, primary cooperative societies, family planning centres, and sub-centers, etc., twenty-four centres in secondorder having the centrality score of $0.25-0.5$. It has been provided the services of sub PHC, senior secondary school, agriculture services, co-operative bank, agricultural credit society, 
branch office, roadways bus stop etc. for the influence area. Sixteen third order centres at block level and tahsil headquarters (centrality index of 0.5 to 10), have administrative services like Police station, Post office, telephone exchange, electricity office etc. while four centres at Tahsil level namely Mariyahu, Shahganj, Machhalishahar, and Kerakat as fourth order. Here the administrative institutions, as well as infrastructural advantages, play a significant role behind its relative functional effect compare to other lower-order centres. and the Jaunpur with CFI value 24.10 is only one fifth-order service centre. It has district headquarters and many other services, it works as the heart for the whole artery of the district, pumping the goods and services to vast hinterlands. The hinterlands of first order are about to $45 \mathrm{sq} . \mathrm{km}$, second order about to $90 \mathrm{~km} 2$, third order about to $190 \mathrm{~km} 2$, fourth order is about to $800 \mathrm{~km} 2$ and Fifth order service centre cover all the area of district.

\section{References}

1. Berry, B.J.L. (1967). Geography of Market Centres and Retail Distribution, Prentice Hall: Englewood Cliffs, London, p. 41.

2. Bracey, H.E. (1953). Town as Rural Service Centres. Transaction of Population. Institute of British Geographers, Vol 19, pp. 95-105.

3. Brush, J.E. (1953). The Hierarchy of Central Places in South -western Wisconsin. Geographical Review, Vol 43, pp. 380-402

4. Chaturvedi, R.(2013). The Hierarchy of Service Centres: A Case study of Allahabad District, Uttar Pradesh, National Geographical Journal of India Vol59(2) ISSN: 0027-9374/1488, pp. 95-104

5. Christaller, W. (1933). Central Places in South Germany (Translated by Baskin, C.W.). Prentice Hall: Engle Wood Cliffs

6. Kayastha, S.L., \& Mishra, S.P. (1981). A Methodological Approach to Identify the Functional Hierarchy of Rural Settlement-A Case Study of Kerakat Tahsil (Jaunpur) in Middle Ganga Plain, In L. R. Singh (ed.). New Perspectives in Geography. Thinker's Library: Allahabad, pp. 123-133.

7. Khan, S., Ahamad, A.(2013). "Hierarchy of Rural Settlement: A Strategy for Balance Regional Development in Aligarh District, International Journal of Scientific Research, Vol2(9) ISSN No. 22778179, pp. 194-197.

8. Losch, A.(1954).The Economics of Location, New Haven: Yale University Press

9. Mallick, R.K. (1998). Development of Spatial and Attribute Database for Planning and Managing Rural Service Centre in Kendrapara District, Orissa, India: A GIS Based Information. Unpublished Thesis.

10. Mandal, R.B. (1960). "Classical Central Place Theory- Central Place System", in R.3. Mandal and V.N.P. Sinha(ed) Recent Trends and Concepts in Geography, III, Concept Publishing Company, New Delhi,

11. Misra, R.P., Sundaram, K.V. \& Rao, P. (1974). A New Strategy for Regional Development, in Regional Development and Planning in India, Vikash Publishing House, Pvt. Itd. Delhi, pp. 204-205.

12. Mishra, S.P. (1985). Service Centre Strategy for Rural Development: A Case Study. Rural System, Vol 3 (3), pp. 227-237.

13. Mishra S.P. (1981/1985). Integrated Rural Area development and Planning: A Geographical Study of Kerakat Tahsil District Jaunpur, Ratan Publication, Varanasi U.P.

14. Misra, R.P., \& Shivalingaih, M. (1970). Growth pole strategy for rural development in India. Journal of Institute of Economic Geography. India, pp. 33-39.

15. Perroux, F. (1950). Economic Space: Theory and Application. Quarterly Journal of Economics, 64, pp. 89-104.

16. Sarkar, S. (2018). analysis of Rural Service Centres Using Spatial Database Approach- A Case study of Chandauli District, Uttar Pradesh, International Journal of Research and Analytical Reviews , Vol5(3) ISSN No. 23495138, pp. 694-704

17. Sen, L.K.et al. (1971). Planning Rural Growth Centres for Integrated Area Development -A Case Study in Myralguda Taluka. National institute of Community Development, Hyderabad.

18. Singh, O.P. (1971). Towards Determining Hierarchy of Service Centres: A Methodology for Central Place Study. National Geographical Journal of India, 17 (4), pp. 171-172.

19. Singh, S.B. (1977). Distribution, Centrality and Hierarchy of Rural Central Places in Sultanpur District (U.P.), India. National Geographical Journal of India, 23(3\&4),pp. 185-194

20. Smailes, A.E. (1944). The urban hierarchy in England and Wales. Geography, 29, pp. 41-51. 